\title{
ADVERSE POSSESSION AFTER J.A. PYE (OXFORD) LTD V THE UNITED KINGDOM
}

\section{Elizabeth Cooke, Professor of Law, University of Reading"}

It is always a pleasure when something really exciting happens in land law. Rarely has there been an excitement to match the decision of the European Court of Human Rights in J.A. Pye (Oxford) Ltd v The United Kingdom. This paper is an attempt by an English lawyer to suggest or predict the effects of that decision for Northern Irish land law. The Land Registration Act (NI) $1970^{2}$ is modelled to a considerable extent upon the English land registration statute of 1925 , whose provisions on adverse possession were the target of the ECtHR's decision. The English statute has been repealed, but Northern Ireland has the 1925 model still, and therefore faces considerable difficulties in working out the consequences of Pye.

The problem therefore stems from English law; it may be that English law can deliver at least part of a solution.

\section{Adverse possession in England and in Northern Ireland: how did we get here?}

\section{Making adverse possession work in registered land}

The basics of the law of adverse possession are known to every law student. Possession of land generates a fee simple in the possessor, ${ }^{3}$ but a fee simple which is defeasible by the dispossessed proprietor, whom we can call (inaccurately on more than one count) the "true owner". Once land has been in the possession of a trespasser for 12 years, the true owner's right of action against him is barred and the true owner's title is extinguished. ${ }^{4}$ The squatter has the best title available; he is now the "owner" of the land.

The fact that possession generates a fee simple has been a considerable problem in Northern Ireland and the Republic, where adverse possession has been so widely used to sort out title on intestacy. ${ }^{5}$ Tenant farmers have died intestate, no grant of representation has been taken out, and the deceased's widow and one of his children have farmed the land; subsequent disputes have been resolved, and title confirmed, by the use of adverse possession. For the title confirmed to be a fee simple would be inappropriate in these cases; and the Irish judges have resorted to the doctrine of estoppel to establish that the squatter took over the lease of the land. Land sold under the

* This paper was written for a meeting of the Judicial Studies Board of Northern Ireland, on 26th January 2006.

1 ECtHR App no. 44302/02 (2005).

2 Hereinafter the "1970 Act (NI)".

3 Tichborne v Weir (1892) 67 LT 735.

4 The authority in GB is the Limitation Act 1980, s.15. In N.I. it is the Limitation (NI) Order 1989, art.26.

5 Wylie, Irish Land Law, $3^{\text {rd }}$ ed., (Dublin, Butterworths, 1997) (hereinafter "Wylie") $1082 \mathrm{ff}$. 
Land Purchase Acts was compulsorily registrable ${ }^{6}$ and so the problem came to be resolved largely by the land registrars, who have taken a robust approach and registered the squatter with the leasehold title. They have thus adopted the "Parliamentary conveyance" approach, outlawed in England in Fairweather v St Marylebone Property Co Ltd ${ }^{7}$ and despite the view taken by the Republic's Supreme Court in Perry v Wood farm Homes Ltd. ${ }^{8}$

So how does the acquisition of title by adverse possession interact, on a technical basis, with the registration of title? Title registration was introduced in England in 1862; it was a rather poor imitation of the very efficient system introduced in New South Wales in 1858 by Sir Robert Torrens. Torrens, whose name is borne by numerous registration systems in the Commonwealth, was an Irishman, from Cork. Ireland very nearly got lucky; Torrens himself came home, became MP for Cambridge and introduced a bill for land registration in Ireland which would have worked rather better than the English statute. As is the way of things, a different Bill was eventually used, and the result was an Irish registration statute very like the English one. ${ }^{9}$ In particular, it did not make registration compulsory; and it made the acquisition of title by adverse possession impossible once title was registered - in keeping with the idea that a registered title is absolute and indefeasible. This produced considerable problems when possession ceased to coincide with ownership. The Land Transfer Act 1897 re-activated the Limitation Acts for registered land, but at the court's discretion - and so did the 1891 registration statute ${ }^{10}$ for Ireland. There are of course two problems about allowing the acquisition of title by adverse possession where title is registered. One is the basic principle that there is a state guarantee of title, which sits ill with the idea that your registered title can be lost because someone else has taken possession of the land. The other is a practical problem of documentation; if title to registered land can be acquired by adverse possession, what happens to the registered title of the dispossessed owner, recorded fair and square on the register? Some title registration systems in the Commonwealth, whether on the English or the Torrens model, do not allow acquisition by adverse possession; some do, and have found various different answers to these two problems. ${ }^{11}$

The Land Registration Act 1925 established for England a very successful title registration system which endured here until a couple of years ago. The 1925 approach to adverse possession in registered land was simple: section 75 stated that the Limitation Acts were to operate "in the same manner and to the same extent" in registered land as in unregistered.

6 Local Registration of Title (Ireland) Act 1891, s.23.

7 [1963] AC 510

8 [1975] IR 104. On this issue see Wallace, (1981) 32 NILQ 254

9 The Record of Title Act 1865. See Dowling, "Of Ships and Sealing Wax: The Introduction of Land Registration in Ireland" (1993) 44 NILQ 360.

${ }_{10}$ Local Registration of Title (Ireland) Act 1891, s.52.

11 Thus it has been remarked that "there is nothing inherently contradictory in having principles of adverse possession operate in registered land, at least if those principles are seen positively as a method of transferring title from one person to another", M. Dixon, "The reform of property law and the Land Registration Act 2002: a risk assessment" in A. Hudson (ed.), New Perspectives on Property Law, Obligations and Restitution (London, Cavendish, 2004). 
Thus the conceptual problem about guaranteed title is swept unceremoniously aside; the practical problem is addressed, by contrast, with unnecessary ceremony. Section 75 goes on to state that once the squatter's twelve years have elapsed, the registered proprietor holds the land on trust for him. He can apply, or course, to be registered in the dispossessed owner's place - and indeed he will do if at any stage he wants to sell the land, in order to make a convincing title for a purchaser. If, before he does that, the registered proprietor sells, the squatter's ownership binds the purchaser, being an overriding interest. ${ }^{12}$

The trust imposed by section 75 of the Land Registration Act 1925 is a conceptual nightmare, ${ }^{13}$ and in any event unnecessary. All that was needed was a provision making the squatter's title an overriding interest. It would thus bind a purchaser; and the nature of the squatter's entitlement would ensure that he would be entitled to rectification of the register under section 82 of the 1925 Act. And that is the solution that the 1970 Act (NI) produced. Section 53 states that the limitation statute applies to registered land as it applies to unregistered land, and among the Schedule 5 interests that affect registered land without registration are "... . all rights acquired, or in the course of being acquired, consequent on the Limitation (NI) Order 1989". ${ }^{14}$

\section{Trends in the law of "adverse" possession}

There has been an uneasiness about the law's requirement that, after some time, we forgive those who trespass against us, and actually reward them with ownership. We can see this uneasiness in the tendency to tighten up the requirements for proof of possession. From $1623^{15}$ until the Real Property Limitation Act 1833, possession had to be shown to be "adverse", that is, not merely a possession of the land but a possession in a manner that was clearly inconsistent with that of the paper owner. The requirement is thus no longer imposed by the legislation but it has proved a persistent notion. It has proved immensely useful as a way of narrowing the goalposts for squatters. In 1879 in Leigh $\mathrm{v}$ Jack $^{16}$ Bramwell LJ revived the notion of adverse possession when he said that "In order to defeat a title by dispossessing the former owner, acts must be done which are inconsistent with his enjoyment of the soil for the purposes for which he intended to use it." Similarly, a century later in Wallis's Cayton Bay Holiday Camp Ltd $\mathrm{v}$ Shell-Mex and BP Ltd ${ }^{17}$ Lord Denning ruled that if a squatter's presence and activities on the land were not inconsistent with the true owner's future intended use of it, he was not in adverse possession, and was present by the implied licence of the owner. This meant that making use of a bit of land for which its owner had no present use, but which he intended to develop later, was deemed to be

12 S.70(1)(f).

13 See Cooke, "Adverse possession: problems of title in registered land" (1994) 14 Legal Studies 1 and Land Registration for the Twenty-First Century: a consultative document Law Comm. No. 254, (London, The Stationery Office 1998) (hereinafter "Law Comm 254") at [10.29] ff.

14 Sch.5, Pt.1, para.14: reference was to the 1958 Act, of course, when the 1970 Act (NI) was enacted.

15 The limitation statute of James I (21 Jac 1, c.16).

16 (1879) 5 Ex D 264 at 273.

17 [1975] QB 94. 
permissible and indeed permitted, so that time could not run in the squatter's favour. The implied licence idea was expressly outlawed by the Limitation Act $1980 ;{ }^{18}$ Bramwell LJ's dictum was rather more long-lasting but was overruled in Buckinghamshire CC v Moran. ${ }^{19}$

In the last couple of decades the English courts' approach has swung in the squatter's favour, and we find various rulings making adverse possession rather easier to establish; in particular, it has been made clear that an offer by a squatter to pay rent for the property does not negate adverse possession provided the offer is not taken up. ${ }^{20}$ And the squatter does not have to intend to claim ownership, only to possess; ${ }^{21}$ he must however intend to exclude the world at large "including, so far as practicable, the paper owner". ${ }^{22}$ Those two statements are not entirely consistent, and the latter is not entirely clear, but the courts have juxtaposed the two as an intended concession to the squatter. The intention is that a squatter who is not a deliberate land thief should not be penalised for the fact that he did not, initially at least, actually intend to deprive anyone of their property.

Another trend in legal thinking has been a fresh awareness of the purpose of adverse possession and a new appreciation of the conceptual problem discussed above, that the limitation of actions to recover land does not sit comfortably with land registration theory. A major influence was Martin Dockray's article, "What is adverse possession for?"23 Dockray highlighted the traditionally quoted objects of the law: to protect defendants from stale claims, to encourage claimants not to sleep on their rights, to ensure that those who possess land may feel confident that they will not be disturbed. He added an idea that is familiar now but which was new at the time, namely the facilitation of the investigation of title to unregistered land. The existence of a limitation period quite simply puts a limit on the length of the abstract necessary. Indeed, the length of title to be deduced, and the length of the limitation period, are directly related (the one is currently 15 years, the other twelve; the one has to be just a little longer than the other). This was a potent influence on the Law Commission's thinking as it prepared for the new law of land registration. ${ }^{24}$

\section{Adverse possession and the Land Registration Act 2002}

In its consultation paper in $1998^{25}$ the Law Commission argued that we needed to move from the rather pedestrian idea of registration of title - the notion that registered title is just an unregistered title seen on a register - to that of title by registration - the fact that registration itself confers title. Consistently with this they sought to reform the law of registered title and to

18 Sch.1 para.8(4).

19 [1990] Ch 623, per Slade LJ at 639 and Nourse LJ at 645F. The Republic's courts have followed this decision: Wylie at p.1089.

20 Ocean Estates v Pinder [1969] 2 AC 19.

21 Moran, supra n. 20 at 643.

22 Moran, supra n. 20 at 640D.

23 [1985] Conv 272.

${ }^{24}$ Law Comm. No. 254, Part X; Land Registration for the Twenty-First Century: a conveyancing revolution Law Comm. No. 271, (London, The Stationery Office 2001) (hereinafter "Law Comm 271"), Part XIV.

25 Law Comm. No. 254. 
make it squatter-proof. This fits well with theory, as discussed; it also provides a potent motivation for large-scale landowners to register their land voluntarily so as to protect it from squatters, in a context where the completion of the register by the registration of all registrable titles was seen as a priority. ${ }^{26}$

Accordingly the Land Registration Act 2002 provides, at section 96, that no period of limitation shall run against any person in relation to a registered estate.

In addition, schedule 6 makes detailed provision for acquisition of title following, but not really as a result of, possession. It provides that after ten years' possession, a squatter may apply to the registrar to have his title registered. The registrar will notify the registered proprietor, and the latter has sixty-five business days ${ }^{27}$ in which to object to the squatter's being registered. If he makes that objection, the squatter will not be registered; and the proprietor has another two years in which to take possession proceedings, if necessary, and remove the squatter. If he does not do so, and the squatter is still in possession two years later, the squatter will be registered as proprietor of the estate. ${ }^{28}$ There is therefore provision for a squatter to take the land (or, rather, the registered estate) if the registered proprietor has abandoned it - or, indeed, if he is careless about opening or answering his post.

Moreover, the Schedule sets out three circumstances in which the squatter can be registered as proprietor despite objection. These are:

- it would be unconscionable because of an equity by estoppel for the registered proprietor to seek to dispossess the squatter, and the circumstances are such that he ought to be registered as proprietor; or

- he has some other entitlement e.g. he is an unpaid vendor, or is entitled to the land under a will; or

- he occupied the land under a reasonable mistake about a boundary.

Notice that in none of these cases will adverse possession by itself extinguish a registered estate. In the first two, adverse possession is not in fact relevant to the entitlement; but it is an added ingredient that enables the claimant to apply to the land registry's Adjudicator rather than to the courts. ${ }^{29}$ In the third case, the added element of mistake means that only the "innocent" squatter will succeed, even in those boundary cases where adverse possession has traditionally been so useful.

\section{Human rights?}

Notice that the Human Rights Act 1998, incorporating into English law the European Convention on Human Rights and Fundamental Freedoms, has not

26 Law Comm No. 271, at [2.9].

27 Land Registration Rules 2003, SI 2003/1417, r.189.

28 That is, of the estate of the dispossessed registered proprietor. The Parliamentary conveyance is legitimised; see above, at n.8.

29 Land Registration Act 2002, ss.73 and 107-111; see Cooke, The New Law of Land Registration (Oxford, Hart Publishing Ltd, 2002), 142-3. 
figured in this narrative. Article 1 of the First Protocol to the Convention states:

"Every natural or legal person is entitled to the peaceful enjoyment of his possessions. No one shall be deprived of his possessions except in the public interest and subject to the conditions provided for by the law and by the general principles of international law.

The preceding provisions shall not, however, in any way impair the right of a State to enforce such laws as it deems necessary to control the use of property in accordance with the general interest or to secure the payment of taxes or other contributions or penalties."

The law of adverse possession has not, before the recent decision in Pye, been seen to fall foul of this principle. ${ }^{30}$ Title to land in this jurisdiction here meaning the United Kingdom - depends upon possession, and the limitation of actions has always been seen as a necessary corollary of this. That vision of the nature of title has necessarily been tempered by a growing realisation that title to registered land does not depend upon possession but upon registration; but not, until recently, by any concern about human rights.

\section{Pye v UK: what did the ECtHR decide?}

\section{Pye in the English courts}

Into this background comes the case of JA Pye (Oxford) Ltd v Graham, litigated and reported at all three levels - Chancery Division, Court of Appeal and House of Lords. ${ }^{31}$ Factually, the case concerned a farm not far from Newbury belonging to JA Pye (Oxford) Ltd. Mr Graham had a grazing licence over the land in question for 1983; when it came to an end Pye asked him to vacate the land, indicating that it was going to be the subject of development. In fact, development did not happen. And Mr Graham kept on using the land both for cutting hay and for grazing. He asked again in 1984 and 1985 for another grazing licence but, on getting no response, understandably stopped bothering. Years passed, and Graham grazed and harrowed and rolled and fertilised and maintained the fences. In 1997 he registered a caution at the Land Registry on the basis that he had obtained title by adverse possession, and in 1998 Pye took action to have the caution cancelled.

So here was a development company, knowing the law or at least well able to get advice, which could easily have recovered possession - Mr Graham would have either left or paid rent if asked. Should the penalty for this be the loss of 25 hectares of development land?

At first instance Neuberger $\mathbf{J}$ said yes; but added that he did so without enthusiasm. Pye's appeal to the Court of Appeal succeeded, on the basis that Graham had not had the requisite intention to establish adverse possession;

30 The discussion of adverse possession in Rook, Property Law and Human Rights (London, Blackstone, 2001) is very brief (pp.205-8); it was written after the Court of Appeal's decision in Pye v Graham .

31 (2000) 81 P \& CR 177; [2001] EWCA Civ 117; [2002] UKHL 30. 
but in the House of Lords he triumphed again, their lordships stressing that he did not need to manifest an intention to own the land. The details of that dispute about the necessary intention are fascinating because they demonstrate just how much room for manoeuvre there is in the requirements for adverse possession. True, the House of Lords has affirmed an orthodoxy; but in the post-1998 world, orthodoxy may have to yield to human rights considerations.

In Pye v Graham it did not, of course; the three courts each expressed different views about the impact of human rights upon the case, but in none was it accepted that human rights had any impact - not even in the Court of Appeal, where Pye was successful. At first instance human rights points were not argued (note that the Human Rights Act 1998 did not come into force until after the judgment was given). At the close of his judgment Neuberger $\mathbf{J}$ simply said: "I believe that the result [in this case] is disproportionate, because, particularly in a climate of increasing awareness of human rights, including the right to enjoy one's own property, it does seem draconian to an owner, and a windfall for the squatter, that, just because the owner has taken no steps to evict a squatter for 12 years, the owners should lose 25 hectares of land with no compensation whatsoever." Human rights was argued strenuously in the Court of Appeal. It was not claimed that section 75 of the Land Registration Act 1925 should be the subject of a declaration of incompatibility under section 4 of the Human Rights Act 1998; only that section 3 should be brought into play, so that the court would interpret the statute so as to avoid a breach of Article 1 of the First Protocol. While Pye succeeded on the facts, the human rights arguments were given very short shrift. This was not a deprivation of possessions, only a barring of the owner's right to evict the squatter, with the extinction of his title a "logical and pragmatic" consequence of this ${ }^{32}$ in any event, if there was a deprivation it was held to be proportionate and in the public interest. ${ }^{33}$ In the House of Lords it was conceded by counsel for Pye that the Human Rights Act 1998 was not relevant and did not operate retrospectively; and therefore human rights points were not argued. Lord Hope of Craighead comments, at [73]:

“. . . one might have expected the law - in the context of a statutory regime where compensation is not available - to lean in favour of the protection of a registered proprietor against the actions of persons who cannot show a competing title on the register. Fortunately ... a much more rigorous regime has now been enacted in Schedule 6 to the Land Registration Act 2002. Its effect will be to make it much harder for a squatter who is in possession of registered land to obtain a title to it against the wishes of the proprietor. The unfairness in the old regime which this case has demonstrated lies not in the absence of compensation, although that is an important factor, but in the lack of safeguards against oversight or inadvertence on the part of the registered proprietor."

32 [2001] EWCA Civ 177 at [45] ff.

33 [2001] EWCA Civ 117, at [52]. 


\section{Beaulane Properties Ltd $\mathrm{v}$ Palmer: human rights to the fore}

Not long after Pye came another adverse possession case: Beaulane Properties Ltd $\mathrm{v}$ Palmer. ${ }^{34}$ At the point when the case was heard, it was known that Pye had applied to the European Court of Human Rights, the defendant being not Graham but the United Kingdom. Beaulane was a case where adverse possession had again been taken of a field for grazing livestock; this time, time had expired after the coming into force of the Human Rights Act 1998 but before the coming into force of the Land Registration Act 2002. And this time the registered proprietor argued human rights: that the effect of section 75 of the Land Registration Act 1925 was to deprive it of its property without compensation contrary to the right guaranteed by Article 1 of the First Protocol.

The registered proprietor succeeded. Nicholas Strauss QC sitting as a Deputy Judge of the High Court found that on the normal interpretation of the Land Registration Act 1925 Beaulane had become a trustee of the registered title for Mr Palmer, who had made out his claim in adverse possession. He went on to consider the argument based on human rights. He noted the line of authority beginning with Leigh $\mathrm{v}$ Jack ${ }^{35}$ in 1879 until Buckinghamshire CC v Moran ${ }^{36}$ and pointed out that when the Land Transfer Act 1897 introduced the operation of the Limitation Acts into registered land, and when the Land Registration Act 1925 was enacted, the law was such that it was going to be very difficult for a landowner to lose his title by inadvertence. Possession had to be adverse, in the sense that it was obviously incompatible with a present use of the land; unless a landowner had actually abandoned his land, he could not be taken by surprise by a squatter's claim. Moran changed this and resumed the doctrine of non-adverse possession. Accordingly limitation did not, after Moran, operate in registered land as the legislature had intended in 1897 and 1925. The Deputy Judge discussed the three limbs of Article 1 of the First Protocol, and concluded that Beaulane had indeed been deprived of its possessions, and that there was no public interest in favour of this deprivation. The reasons justifying the operation of the limitation of actions to recover land are largely specific to unregistered land - in particular the promotion of certainty and the facilitation of conveyancing - as indeed the Law Commission argued, in its consultative document, ${ }^{37}$ in favour of the reforms it proposed.

This left the court with the obligation to operate section 3 of the Human Rights At 1998: to interpret the relevant statutory provision in such a way as to make its operation compatible with the convention. Counsel for Beaulane argued for the option of declaring the law on the limitation of actions to recover land to be inapplicable to registered land. In view of the express provisions of the Land Registration Act 1925 Strauss QC dismissed this option as an act of "judicial vandalism". ${ }^{38}$ Instead, and with admirable creativity, the Deputy Judge held that section 75 of the Land Registration Act 1925 was to be interpreted in accordance with the case law in existence at the

34 [2005] EWHC 1071 (Ch.).

35 (1879) 5 Ex D 264, CA; see above at n.16.

36 [1990] Ch 623; see above at n.19.

37 See n.25 above.

38 [2005] EWHC $1071(\mathrm{Ch})$ at [210]. 
time of its enactment: namely, as if Leigh $\mathrm{v}$ Jack remained authoritative. This meant that Palmer's case failed. He had used the disputed land for grazing for a period during which the registered proprietor had no use for it. Accordingly his possession was not adverse and did not establish a title for him.

He also held that, had Palmer's claim succeeded, there would have been no possibility of reinterpreting the statutory provisions in such a way as to create a right for the dispossessed proprietor to be compensated for his loss; but in view of his finding in Palmer's case, the issue of compensation did not arise.

Beaulane was a shock. Leigh $\mathrm{v}$ Jack had been felt to be so outdated and so thoroughly eradicated that it seemed unthinkable that it should be revived. But a bigger shock was to come.

\section{Pye in the ECtHR}

The judgment in Beaulane was given with the express intention of influencing the ECtHR in Pye v UK. And it seems to have done so. ${ }^{39}$ The judges of the ECtHR were faced with a claim by Pye that the UK had deprived it of its possessions without compensation by allowing the Limitation Acts to operate in registered land (i.e. by enacting section 75 of the Land Registration Act 1925 and allowing it to remain on the statute book). Pye succeeded, the ECtHR ruling in its favour by a four to three majority.

The reasoning in the ECtHR judgment focuses on the government's argument that there is no deprivation of possessions in adverse possession cases. The traditional English, feudal view that what we colloquially call "ownership" is in fact a limited right, always subject to the possibility of dispossession, is met by a very European concept of ownership. Ownership is an absolute; and a statute of Limitations, with a provision for the extinguishment of title without compensation, is a deprivation of possessions, which bites upon the property at the moment when the title is extinguished, rather than being a condition of that ownership ab initio. ${ }^{40}$ The court noted the government's argument that the deprivation if there was one, was the result of Pye's inactivity, and rejected it, laying the blame squarely upon the statute. ${ }^{41}$

As to the issue of legitimate aim, the court noted that limitation periods are not in general incompatible with the Convention. ${ }^{42}$ The court noted the Law Commission's arguments and the amendments to our law of registered title in the Land Registration Act 2002; and that the operation of limitation has not been entirely eliminated and cannot be said to serve no public interest in registered land. ${ }^{43}$ But it held that in the current case, given the scale of the loss and the absence of compensation, it held that the operation of the law so as to deprive Pye of its title was "an individual and excessive burden and

\footnotetext{
39 ECtHR App. no. 44302/02 (2005) at [33]

40 ibid., at [50]

41 ibid., at [56].

42 ibid., at [63].

43 ibid., at [67].
} 
upset the fair balance between the demands of the public interest on the one hand and the applicants' right to the peaceful enjoyment of their possession on the other." ${ }^{44}$ There was therefore a violation of Article 1 of Protocol 1 of the Convention. The court gave particular weight to the reasons given for the changes in the 2002 statute, "and to the view of the Law Commission and the Land Registry as to the lack of cogent reasons to justify the system of adverse possession as it applied in the case of registered land." 45 There is an element of "you knew it was wrong, didn't you!"

Notice the limitations on the decision. It is relevant only to registered land; in unregistered land there is ample justification for the continuance of the current law. ${ }^{46}$ It does not state that all cases of adverse possession in registered land under our 1925 Act will be unlawful; nor does it state that all applications of Schedule 6 of the 2002 Act will be lawful.

There was a strong dissent in the ECtHR, on the bass that as property developers with ample access to legal advice, Pye could easily have avoided the difficulty. The UK government has sought leave to appeal to Grand Chamber of the European Court of Human Rights.

\section{Consequences for England and Wales}

In the House of Lords in Pye v Graham, Lord Bingham of Cornhill said: ${ }^{47}$

"It is reassuring to learn that the Land Registration Act 2002 has addressed the risk that a registered owner may lose his title by inadvertence."

It is not entirely obvious that the provisions of the Land Registration Act 2002 will eliminate human rights problems for the future.

Of the three exceptions in Schedule $6,{ }^{48}$ two depend upon an entitlement independent of adverse possession. The third, relating to genuine mistakes about boundaries, is likely to apply only in a small number of cases and, more importantly, to relate to only very small areas of land. Boundary disputes are well-established as an area where adverse possession has a uniquely useful role to play in the resolution of disputes, the avoidance of conveyancing costs and, in some cases, the avoidance of costly demolition operations (consider the possibility of a garage encroaching over a boundary by just a few inches). So when title is transferred under one of these exceptions, there are strong arguments in favour of this being a deprivation in the public interest.

The main weakness would seem to be the possibility of losing land through inadvertence, through failure to respond to the registrar's notice. This is a problem because the majority in the ECtHR seemed to hold that the cause of the loss was not inadvertence (which was after all a conspicuous feature of Pye itself). Note that the ECtHR's approval expressed, at [74], of the new provisions in the 2002 Act refers to the three exceptions in Schedule 6 but

44 ibid., at [75].

45 ibid., at [74].

46 See above at n.24.

47 [2002] UKHL 30, at [2].

48 See above, text following n.29. 
not to the possibility of title being lost simply because the registered proprietor does not object. Moreover, the 2002 Act (or, rather, rules thereunder ${ }^{49}$ ) is quite strict: there is a relatively short period in which a registered proprietor can respond to the registrar's notification and object to the registration of the squatter.

This option might be better explored if there were to be a successful appeal to the Grand Chamber on the basis that Pye itself was responsible for its loss. In that event, loss of title under the 2002 Act by failure to respond to the registrar's notice might seem safe, unless the period itself is too short. It is conceivable that an elderly or disabled registered proprietor, or one absent from his address for service for good reason, might miss the notice and lose his land through inadvertence. ${ }^{50} \mathrm{He}$ might then claim to be suffering a disproportionate burden, and the court would then have to examine the justification for the period of sixty-five business days.

As a separate issue, however, it is possible that the courts may still hear claims of adverse possession under the 1925 Act, where time expired before the Land Registration Act 2002 came into force. ${ }^{51}$ This will give rise to considerable problems, in the same terms as those faced in Northern Ireland; the issue is discussed below.

What can we say about the registered proprietor who has lost his title already under the 1925 Act, but who could now allege that the loss was a violation of Article 1 of Protocol 1? It appears that he has no remedy. He cannot proceed again against the squatter, for the time limit for appeal will have expired. He cannot apply to Strasbourg, where a six-month time limit is operated. ${ }^{52}$ And although the Human Rights Act 1998 allows him to take action against a public authority, in this case the court, there is a one year limitation period, ${ }^{53}$ and in any event there is no right to damages where the public authority is a court except in cases of arrest or detention contrary to Article 5 of the Convention. ${ }^{54}$ The registered proprietor who has lost his title in the past would not appear to have a source of redress now.

\section{Consequences for Northern Ireland}

Looking now at Northern Ireland, and taking the latter point first, it would appear that claims from registered proprietors who have lost their title in the past are not going to arise, for the reasons just explained. The difficulty is going to arise in new cases, where a squatter claims title by adverse possession. What are the courts going to do?

49 See n.28, above.

50 Note the provisions enabling the proprietor to give the registry up to three addresses for service; of which one must be a postal address; the others may be electronic, or a document exchange: Land Registration Rules 2003 SI 2003/1417, r. 198.

51 There are some transitional provisions, which would be tedious here; see Cooke, Land Registration (n.29 above) at 152.

52 Wadham, Mountfield and Edmundson, Blackstone's Guide to the Human Rights Act, $3^{\text {rd }}$ ed. (Oxford, OUP, 2003), 220.

53 Human Rights Act 1998 s.7(5).

54 S.9(3). 
In principle, there are three options, assuming a claim that would have been successful pre-Pye:

1. Interpret the limitation statute in such a way that the claimant fails (as did the English court in Beaulane ${ }^{55}$ ).

This involves looking back to the line of authority running from Leigh $\mathrm{v}$ Jack $^{56}$ to Buckinghamshire CC v Moran.$^{57}$ If the case concerns inheritance and intestacy, this would represent a more startling break with tradition even than it did in Beaulane.

2. Allow the squatter's claim because it would also succeed under one of the three exceptions in Schedule 6 to the Land Registration Act 2002: the claimant has some other entitlement, or he has made an honest mistake about boundaries, or the defendant has abandoned the land and is to blame for his loss - thus distinguishing Pye.

This involves some faith in the provisions of the 2002 Act; but that faith would seem justified if the individual circumstances are examined carefully. If there is a genuine boundary mistake, or if the claimant has some other entitlement, there is every chance that he may succeed without there being any violation of the Convention.

3. Allow the squatter's claim if it appears that the registered proprietor's own inadvertence or inactivity is the cause of his loss.

This is NOT a safe option for the courts at the moment; it could only be pursued if there is an appeal from the ECtHR to the Grand Chamber in Pye v $U K$, and only if that appeal were to succeed on the basis that Pye's own fault caused its loss. Even so, great care would be needed; recall that Pye was a development company with ready access to legal advice, so that more might be expected of it than of a private individual.

4. Allow the squatter's claim because the human rights considerations operative in Pye are not operative in Northern Ireland.

The Northern Irish courts could take the view that the demographics, economics and legal tradition in Northern Ireland and the Republic make a difference to the argument as to the potential justification for the deprivation of property without compensation. The extensive use made of adverse possession over many years for resolving problems following intestacy could be said to justify the deprivation of property as being "in the public interest".

Among the arguments in favour of doing this are the wealth of case law on this use of adverse possession in Northern Ireland and the Republic, ${ }^{58}$ and the special legislative provision in both jurisdictions to facilitate the operation of adverse possession in this context. Thus in the Republic, the limitation period is reduced from 12 to 6 years in respect of estates of deceased person. ${ }^{59}$ And in both the Republic and in Northern Ireland legislation has confirmed the courts' rulings that a personal representative is not a trustee for the purposes

\footnotetext{
55 See above at $\mathrm{n} .35 \mathrm{ff}$.

56 (1879) 5 Ex D 264

57 [1990] Ch.623. See above, text at n.20.

58 Of which the material in Wylie, chap.23, is but a selection.

59 Succession Act 1965, s.126.
} 
of the statute of limitations ${ }^{60}$ - this enables, for example, a surviving spouse to acquire title to the estate by adverse possession and to bar the interests of the beneficiaries, despite the fact that as administrator of the estate and therefore a trustee she would otherwise be unable to do so.

The difficulty with this argument is that it is rare for an argument to succeed on these grounds in the absence of provision for compensation, in the Strasbourg jurisprudence (to which the domestic courts must give effect in accordance with section 2 of the Human Rights Act 1989). However, the ECtHR in Pye referred to some cases where deprivation without compensation had been held to be permissible. ${ }^{61}$

5. Make a declaration of incompatibility (of course, only the higher courts have power to do this ${ }^{62}$ ).

The final card in the courts' hands is to declare section 53 of the 1970 Act (NI) to be incompatible with the Human Rights Act 1998. This is a dramatic option. It does not change the result in the individual case; it will, assuming that it is acted on by the legislature and results in an amendment of the 1970 Act (NI) change the law of adverse possession for all subsequent cases. It would pave the way for the introduction in Northern Ireland of something to match the adverse possession provisions in section 96 and schedule 6 of the Land Registration Act 2002 in England. In view of the possibility of an appeal against the ECtHR's decision in Pye v $U K$, there may be an argument for not doing this until it is known whether or not there will be an appeal, and what its outcome might be.

This paper has dealt only with land whose title is registered. The decision in $P y e \mathrm{v} U K$ was expressly limited to registered title, and it can have no effect upon unregistered title. Where title is unregistered, the public interest in having a system of acquisition of title by adverse possession has not seriously been questioned. However, in view of what has been said above, we have to consider whether or not the lack of any scope for compensation might be a route for challenge in the future. The same must be true where land is registered under the deeds registration system. ${ }^{63}$ Deeds registration does not guarantee title, and does not always make deduction of title straightforward; accordingly the existence of a system of adverse possession must have the same utility as it has in unregistered land but, again, the absence of compensation may give rise to difficulties.

60 Statute of Limitations 1957, s.2(2); Limitation (NI) Order 1989, art.45(1).

61 ECtHR App. no. 44302/02 (2005) at [47]

62 Human Rights Act 1998 s.4(2).

63 Registration of Deeds Act (NI) 1970. 